\title{
PENGEMBANGAN MANAJEMEN KOPERASI DI PONDOK PESANTREN PERGURUAN ISLAM SALAFIAH KABUPATEN BLITAR
}

\author{
Marsudi, Usman Arief, Siti Zahrok ${ }^{*}$
}

\begin{abstract}
Abstrak
Pondok pesantren (Ponpes) merupakan salah satu lembaga pendidikan Islam tertua di Indonesia, keberadaan dan perannya dalam mencerdaskan kehidupan bangsa telah diakui oleh masyarakat. Dalam perkembangannya pondok pesantren berfungsi sebagai pusat bimbingan dan pengajaran ilmu-ilmu agama Islam telah banyak melahirkan ulama, tokoh masyarakat dan mubaligh. Seiring dengan laju pembangunan dan tuntutan zaman serta perkembangan ilmu pengetahuan dan teknologi, pondok pesantren telah melakukan berbagai inovasi untuk meningkatkan peran dan sekaligus memberdayakan potensinya bagi kemaslahatan lingkungannya. Salah satu bentuk adaptasi nyata yang telah dilaksanakan adalah pendirian koperasi di lingkungan Ponpes dan dikenal dengan sebutan Koperasi Pondok Pesantren. Dalam upaya pemberdayaan dan pengembangan koperasi di lingkungan pondok pesantren dipandang perlu melakukan pendidikan dan pelatihan manajemen koperasi agar koperasi yang sudah ada berkembang menjadi koperasi yang lebih profesional dan membawa kemaslahatan bagi anggota serta masyarakat sekitar.
\end{abstract}

Kata kunci: pengembangan, manajemen koperasi, pondok pesantren

Pondok pesantren merupakan pilar penting penopang kehidupan masyarakat di Jawa Timur terutama di wilayah-wilayah hampir sebagian besar pedesaan. Secara kultural, pondok pesantren yang berfungsi lembaga dakwah Islam, namun sekaligus sebagai lembaga pendidikan yang sejajar dengan pendidikan formal. Sudah lazim di wilayah pedesaan, setiap anak begitu setelah tamat SD atau SMP akan melanjutkan ke pesantren. Hal ini dikarenakan biaya yang lebih murah dibanding sekolah formal dan juga karena pesantren sebagai lembaga informal dipandang merupakan lembaga penting penggerak dinamika masyarakat pedesaan.

Program pendidikan di pondok pesantren pada dasarnya bertujuan utama dakwah agama (Islam) namun dalam kenyataannya dituntut memainkan peran lebih bahkan sebagai tumpuan untuk menyikapi serta harapan dapat menyelesaikan berbagai persoalan dalam masyarakat pedesaan, mulai dari persoalan keagamaan, sosial, politik sampai ke persoalan ekonomi. Ketidak sesuaian kondisi dengan beban

* Dosen UPM Soshum ITS

jsh Jurnal Sosial Humaniora, Vol 4 No. 2, November 2011 
berat peran yang harus dipikul pondok pesantren maka pelatihan manajemen koperasi pondok pesantren ini sangat penting untuk diselenggarakan.

Sementara ini terdapat pandangan yang berkembang di masyarakat bahwa kaum pondok pesantren atau sering disebut kaum sarungan adalah kaum yang kolot,primitif, kurang rasional serta kurang produktif. Untuk menepis pandangan ini adalah dengan memberdayakan kaum santri pondok pesantren dengan sebuah sistem yang terorganisasi yaitu koperasi. Koperasi ini menjadi pilihan karena dalam sistem koperasi semua anggota bisa berpartisipasi aktif dalam sistem tersebut. Dalam rangka mewujudkan gagasan tersebut, maka diperlukan langkah pendahuluan yaitu pembekalan pengetahuan tentang seluk - beluk koperasi kepada para santri pondok pesantren khususnya yang ada di Kabupaten Blitar.

Pondok pesantren (Ponpes) merupakan salah satu lembaga pendidikan Islam tertua di Indonesia, di mana keberadaan dan perannya dalam mencerdaskan kehidupan bangsa telah diakui oleh masyarakat. Dalam perkembangannya pondok pesantren berfungsi sebagai pusat bimbingan dan pengajaran ilmu-ilmu agama Islam atau disebut "tafaqquh biddin" telah banyak melahirkan ulama, tokoh masyarakat dan mubaligh. Seiring dengan laju pembangunan dan tuntutan zaman serta perkembangan ilmu pengetahuan dan teknologi, pondok pesantren telah melakukan berbagai inovasi untuk meningkatkan peran dan sekaligus memberdayakan potensinya bagi kemaslahatan lingkungannya. Salah satu bentuk adaptasi nyata yang telah dilaksanakan adalah pendirian koperasi di lingkungan Ponpes dan dikenal dengan sebutan Koperasi Pondok pesantren atau lebih dikenal dengan istilah "Kopontren".

Keberadaan gerakan koperasi di kalangan pesantren sebenarnya bukanlah cerita baru, sebab pendiri koperasi pertama di bumi Nusantara adalah Patih Wiriatmadja, seorang muslim yang sadar dan menggunakan dana masjid untuk mengerakan usaha simpan pinjam dalam menolong jamaah yang membutuhkan dana. Tumbuhnya gerakan koperasi di kalangan santri merupakan salah satu bentuk perwujudan dari konsep ta'awun (saling menolong), ukhuwah (persaudaraan), tholabul ilmi (menuntut ilmu) dan berbagai aspek ajaran Islam lainnya. 
Eksistensi Koperasi Pondok pesantren dapat ditinjau melalui tiga dimensi yaitu sebagai pendukung mekanisme kehidupan ekonomi Pondok pesantren, sebagai pembinaan kader koperasi pedesaan dan sebagai stimulator sosio-ekonomi masyarakat desa di sekitar Ponpes. Dewasa ini, Kopontren telah berkembang dan menjadi semacam representasi lembaga ekonomi santri yang diinisiasi secara bottom up dengan ciri kemandirian yang khas.

Sejalan dengan itu, dipandang penting memberikan dukungan dalam upaya pengembangan managemen koperasi khususnya di lingkungan pondok pesantren. Bentuk dukungan yang dilakukan adalah melakukan pengabdian kepada masyarakat di pondok pesantren dengan memberikan pendidikan dan pelatihan manajemen koperasi.

Pondok pesantren yang dipilih adalah Pondok pesantren Perguruan Islam Salafiah yang berada di Kabupaten Blitar. Pondok pesantren ini dipilih dengan alasan bahwa koperasi di pondok pesantren ini sudah ada, namun belum mengalami perkembangan yang signifikan terutama dalam pengelolaan majemen secara professional, serta masih minimnya pemanfataan teknologi seperti Komputer untuk mempermudah pengelola/pengurus dalam manajemen koperasi serta masih terbatasnya jaringan yang dikembangkan oleh pihak pengurus koperasi dengan masyarakat di sekitar sehingga segmen pasar masih terbatas pada santri sebagai angota maupun sebagai konsumen. Terkait dengan hal tersebut, Tim pengabdi berasumsi bahwa penting melakukan pendidikan dan pelatihan hhususnya menyangkut manajemen pengelolaan koperasi agar koperasi Pondok pesantren lebih berkembang dan bermanfaat bukan hanya bagi anggota (santri) tapi juga bermanfaat secara luas untuk masyarakat sekitar.

\section{Identifikasi Permasalahan Koperasi Pondok pesantren}

Berdasarkan hasil observasi di lapangan ditemukan beberapa permasalahan sebagai berikut.

1. Koperasi pondok pesantren di Kabupaten Blitar belum menunjukkan perkembangan yang signifikant terutama jika dilihat dari indikaor kesejahteraan dari para anggotanya, pangsa pasar koperasi, serta manajemen pengelolaan dan pertanggungjawaban pengelola serta keterbatasan pendanaan. Di samping itu, 
manajemen pengelolaan masih sangat tergantung pada Ketua Yayasan Pondok pesantren. Koperasi yang maju dan professional ditandai dengan partisipasi atau pelibatan secara penuh dari angota-anggotanya dalam mengelola koperasi, baik dari manejemen pengelolaannya maupun dalam produk atau out put dari apa yang dikelola joperasi tersebut.

2. 2). Perluasan pangsa pasar belum berhasil dilakukan dan masih terbatas kepada segment tertentu khususnya para santri di lingkungan sendiri. Dari hasil pengamatan di lapangan, belum terlihat adanya partisipasi aktif dari anggota santri serta kinerja dari pengurus yang masih standart, sehingga perkembangan koperasi yang ada masih sebatas untuk memenuhi kebutuhan dasar anggota (santri) saja, sehingga santri hanya berfungsi sebagai konsumen. Di samping itu secara umum, koperasi yang ada belum sampai membawa manfaat nyata bagi masyarakat yang ada di sekitarnya.

3. 3) Pengelolaan dan pertanggungjawaban dana anggota masih menjadi kewenangan penuh pihak Yayasan Pondok pesantren. Untuk menuju koperasi yang modern dan professional harus transparan dan akuntable antara pegurus dan anggota melalui Rapat Tahunan dan pembagian SHU (Sisa Hasil Usaha) kepada para anggotanya.

4. Berdasarkan permasalahan tersebut, maka dipandang penting memberikan pelatihan Tentang Manajemen Koperasi dengan tujuan agar koperasi yang sudah berjalan lebih berkembang ke arah koperasi yang professional, maju dan membawa kemaslahatan bagi santri, yayasan pondok pesantren serta bagi masyarakat sekitar.

Dari Identifikasi permasalahan tersebut, maka permasalahan yang akan dijawab untuk melakukan tindakan nyata melalui kegiatan pengabdian adalah:

1. Bagaimana bentuk dan jenis program diklat yang dibutuhkan untuk pembinaan Koperasi Pondok pesantren?

2. Sejauh manakah efektivitas program diklat dalam menunjang pertumbuhan Koperasi Pondok pesantren?

3. Upaya apa saja yang perlu dilakukan untuk meningkatkan kinerja Koperasi Pondok pesantren? 
Tujuan dan manfaat dari program Pengembangan Manajemen Koperasi di Pondok pesantren dengan model Pendidikan dan pelatihan adalah:

1. Merealisasikan visi dan misi LPPM ITS Surabaya dalam pemberdayaan masyarakat

2. Menjalin kerja sama antara ITS Surabaya dengan Pemerintah Daerah, serta masyarakat Blitar demi mencapai kesejahteraan dan kemajuan bersama

3. Memberdayakan masyarakat secara umum sehingga akan berdampak pada peningkatan taraf hidup.

4. Menginspirasi calon pengabdi masyarakat lain untuk menindaklanjuti kegiatan pengabdian yang telah dilaksanakan dan dihasilkan dalam pengabdian ini.

\section{Koperasi Pondok Pesantren Institut Pendidikan Islam Salafiyah Blitar}

Prosedur pendirian koperasi Pondok pesantren APIS ini mengacu pada peraturan perundang-undangan di Indonesia, UUD 1945 dan UU Koperasi. Prinsip koperasi Menurut UU No. 25 tahun 1992 Pasal 5 disebutkan prinsip koperasi, yaitu: Keanggotaan bersifat sukarela dan terbuka Pengelolaan dilakukan secara demokratis Pembagian Sisa Hasil Usaha (SHU) dilakukan secara adil sebanding dengan besarnya jasa usaha masing-masing anggota (andil anggota tersebut dalam koperasi Pemberian balas jasa yang terbatas terhadap modal Kemandirian Pendidikan perkoprasian kerjasama antar koperasi

Mekanisme pendirian koperasi terdiri dari beberapa tahap. Pertama-tama adalah pengumpulan anggota, karena untuk menjalankan koperasi membutuhkan minimal 20 anggota. Kedua, Para anggota tersebut akan mengadakan rapat anggota, untuk melakukan pemilihan pengurus koperasi ( ketua, sekertaris, dan bendahara ). Setelah itu, koperasi tersebut harus merencanakan anggaran dasar dan rumah tangga koperasi itu. Lalu meminta perizinan dari negara. Barulah bisa menjalankan koperasi dengan baik dan benar. Setelah penyajian materi dilanjutkan dengan pemberian pertanyaan dan peserta dapat menjawab dengan baik. 


\section{Pengelolaan Organisasi Koperasi}

Pengampu memberikan materi manajemen koperasi yang diambil dari bukubuku manajemen koperasi. Inti pengelolaan koperasi dapat disampaikan seperti berikut. Pengelolaan organisasi koperasi, agar koperasi bisa berjalan dengan baik, koperasi perlu dijalankan secara profesional dan melibatkan unsur-unsur antara lain rapat anggota, pengurus, anggota, dan badan pengawas. Ketiga unsur itu berkerja sama untuk mencapai tujuan koperasi.

\section{Rapat Anggota}

Rapat Anggota dalam koperasi merupakan ukuran keberhasilan koperasi dari waktu ke waktu. Selain itu arena rapat anggota dihadiri oleh seluruh anggota, rapat ini juga merupakan rapat pemegang kekuasaan tertinggi dalam koperasi. Sejumlah keputusan penting diambil dalam rapat anggota ini antara lain:
a. Anggaran Dasar
b. Kebijakan umum di bidang organisasi, manajemen, dan usaha koperasi
c. Pemilihan, pengangkatan, pemberhentian pengurus, dan pengawas
d. Rencana kerja, rencana anggaran pendapatan dan belanja koperasi, serta pengesahan laporan keuangan
e. Pertanggungjawaban pelaksanaan fungsi pengurus
f. Pembagian sisa hasil usaha, dan
g. Penggabungan, peleburan, pembagian, dan pembubaran koperasi.

\section{Menanamkan Jiwa Koperasi}

Koperasi pesantren (Kopentren) sangat membantu bagi para santri untuk mengembangakan potensinya dalam bidang ekonomi dan sebagai latihan bertanggung jawab dan kemandirian santri. Pembentukan Koperasi Pesantren di kalangan santri dilaksanakan dalam rangka menunjang pendidikan santri dan latihan koperasi. Dengan demikian, tujuan pembentukannya tidak terlepas dari tujuan pendidikan dan program pemerintah dalam menanamkan kesadaran berkoperasi sejak dini. Selain itu, pendirian koperasi di pesantren mulai dari tingkat dasar sampai menengah diharapkan menjadi sarana bagi santri untuk belajar melakukan usaha 
kecil-kecilan, mengembangkan kemampuan berorganisasi, mendorong kebiasaan untuk berinovasi, belajar menyelesaikan masalah, dan sebagainya.

Dalam mendirikan koperasi sekolah, diperlukan pertimbangan-pertimbangan agar selaras dengan apa yang diharapkan. Tujuan koperasi sendiri adalah memajukan kesejahteraan anggota pada khususnya dan masyarakat pada umumnya. Serta ikut membangun tatanan perekonomian nasional dalam rangka mewujudkan masyarakat maju, adil dan makmur berlandaskan Pancasila dan UUD 45. Pada dasarnya koperasi bisa menyerap tenaga kerja, mengurangi angka kemiskinan.

Setelah pengampu memberikan materi tentang kesadaran berkoperasi kepada para santri, kemudian mendapatkan tanggapan yang sangat antusias. Antusiasme ini mengindikasikan bahwa para santri sangat menyadari akan pentingnya berkoperasi. Jika dikaitkan dengan ajaran agama, berkoperasi tidak bertentangan dengan ajaran agama Islam. Hal hal ini ditegaskan baik dari Drs. Achmad sebagai pemateri maupun KH. Imam Sughrowardi sebagai pimpinan pondok pesantren APIS Blitar.

\section{Hasil Pelaksanaan Kegiatan Pendidikan Dan Pelatihan Manajemen Koperasi}

Pendidikan dan Pelatihan Pengembangan manajemen koperasi di Pondok pesantren APIS Blitar ini merupakan model pengembangan dan pelatihan yang ditujukan untuk pengurus dan para santri dengan harapan selanjutnya nanti dapat disebarluaskan untuk masyarakat di sekitar pondok pesantren yang ada di wilayah Blitar. Adapun pelaksanaan kegiatan pelatihan pengembangan manajemen koperasi ini meliputi, Perencanaan, Persiapan pelaksanaan, pelatihan, Monitoring dan Evaluasi. Rincian pelaksanaan aktivitas tersebut adalah sebagai berikut:

\begin{tabular}{|c|l|l|c|}
\hline Nama & Bentuk Aktivitas & \multicolumn{1}{|c|}{ Materi } & Waktu \\
\hline Aktivitas 1 & $\begin{array}{l}\text { Pembekalan } \\
\text { dengan ceramah }\end{array}$ & $\begin{array}{l}\text { Materi Ttg Koperasi dan Manajemen } \\
\text { Koperasi }\end{array}$ & 1 hari \\
\hline Aktivitas 2 & Diskusi & Memberi Tema Diskusi & 1 hari \\
\hline Aktivitas 3 & Simulasi & $\begin{array}{l}\text { Kelompok membagi anggota untuk } \\
\text { bertindak/berperan }\end{array}$ & $\begin{array}{l}\text { Sampai } \\
\text { selesai }\end{array}$ \\
\hline Aktivitas 4 & Demonstrasi & $\begin{array}{l}\text { Pemateri mendemontrasikan alat atau } \\
\text { benda yang dapat memperkuat } \\
\text { pemahaman peserta pelatihan }\end{array}$ & $\begin{array}{l}\text { Sampai } \\
\text { Selesai }\end{array}$ \\
\hline Aktivitas 5 & Penugasan & Peserta diberi tugas membuat laporan & \\
\hline
\end{tabular}

Sumber: Diolah dari laporan Pelaksanaan Pengabdian Kepada Masyarakat Oleh Tim Pengabdi UPM-Soshum-ITS 2011. 
Untuk mencapai tujuan yang telah ditetapkan, dalam proses pembelajaran digunakan berbagai metode dengan harapan dapat saling melengkapi kelebihan dan kekurangan masing-masing metode. Adapun metode yang diaplikasikan dalam proses pembelajaran ini adalah:

1. Metode ceramah

Penceramah memberikan materi perkoperasian yang diasumsikan belum pernah diterima oleh para santri sebagai peserta pelatihan koperasi.

2. Metode diskusi

Pengampu mengajukan problem perkoperasian yang harus dipecahkan oleh para peserta pelatihan koperasi secara berkelompok.

3. Metode simulasi

Pengampu menginstruksikan kelompok-kelompok peserta melakukan tindakan seperti keadaan sebenarnya dalam masyarakat.

4. Metode demonstrasi

Pengampu melakukan pembelajaran dengan cara mendemontrasikan alat atau benda yang dapat memperkuat pemahaman peserta pelatihan.

5. Metode portofolio.

Pengampu memberikan tugas-tugas perkoperasian yang harus dikumpulkan dalam bentuk laporan tertulis.

\section{Tahap-tahap Dalam pelaksanaan kegiatan Pendidikan dan Pelatihan:}

1. Observasi dan pendataan pondok pesantren di Kabupaten Blitar yang memiliki koperasi yang akan diikutserta dalam pendidikan dan pelatihan.

2. Pendataan santri yang mengikutipendidikan dan pelatian

3. Pendataan jenis pelatihan terkait manajemen koperasi yang diinginkan oleh pengurus koperasi dan peser ta pelatihan. Panitia menghubungi tenaga ahli pada jenis usaha yang diinginkan oleh peserta untuk memberikan workshop.

4. Pelaksanaan kegiatan pendidikan dan pelatihan.

5. Pelaksanaan aktivitas penyusunan portofolio bagi peserta pendidikan dan pelatihan.

6. Konsultasi dan evaluasi pelaksanaan proposal usaha

7. Penyusunan Laporan. 
Dengan adanya pendidikan dan pelatihan pengembangan manajemen koperasi di lingkungan Pondok pesantren, diharapkan ada transformasi pengetahuan dan teknologi dari perguruan tinggi, sehingga bisa membawa perubahan yang lebih baik bagi pondok pesantren dalam mengelola koperasi yang lebih professional dan berbasis teknologi. Dalam pelatihan majemen koperasi para santri juga diberi pembekalan pemanfaatan teknologi yaitu penggunaan komputer dalam mengelola koperasi. Pemanfaatan teknologi dengan menggunakan perangkat komputer diharapkan dapat memacu sikap kreatif dan inovasi para pengurus, pengelola dan parasantri dalam menghadapi kendala - kendala terkait pengelolaan koperasi.

\section{Bentuk Kegiatan Dan Kendala Yang Dihadapi}

Kegiatan pengabdian pada masyarakat ini berbentuk pelatihan. Dari beberapa jenis pelatihan yang ditawarkan, yaitu: Manajemen pengembangan koperasi, pemanfaatan teknologi dalam komputer dalam pengelolaan koperasi pondok pesantren. Menumbuhkan jiwa koperasi dan wirausaha para santri, membangun relasi pondok pesantren dengan masyarakat dalam mengembangkan koperasi.

Penentuan materi pembekalan dalam pendidikan dan pelatihan dalam Pengembangan manajemen koperasi didasarkan pertimbangan bahwa:

1. Masih terbatasnya pemahaman tentang manajemen koperasi dari pihak pengelola/pengurus, dan para santri. Melalui pendidikan dan pelatihan diharapkan para santri punya bekal yang cukup sehingga nanti dapat mengembangkan managemen koperasi yang lebih baik.

2. Masih minimnya penggunaan teknologi seperti pemanfaatan komputer dalam membantu mengelola koperasi sehingga pengelolaan masih konvensional dan kurang efektif dan produktif.

3. Masih terbatasnya jaringan yang dibangun pengelola koperasi dengan masyarakat sekitar sehingga segmen pasar dari koperasi yang dikembangkan masih terbatas pada pemenuhan kebutuhan para santri.

Untuk itu pelatihan pengembangan manajemen koperasi di pondok pesantren APIS ini lebih fokus pada pembekalan pendidikan dan pelatihan dalam mengelola 
kopreasi serta pentinnya pemanfaatan teknologi komputer dan membangun jejaring untuk mengembangkan dan memperluas segmen pasar dari koperasi pondok pesantren sehingga keberadaan koperasi pondok pesantern juga dapat dirasakan bagi masyarakat sekitar.

\section{Peserta}

Peserta dari pendidikan dan pelatihan pengembangan manajemen koperasi di pondok pesantren ini dadalah para santri dari pondok pesantren Perguruan Islam Salafiah Blitar, dan para pengurus dan ketua dari yayasan pondok pesantren.

Jumlah peserta yang mengikuti pendidikan dan pelatihan sekitar 25 orang yang teridiri dari para santri, pengurus pondok dan dari yayasan pondok pesantren Perguruan Islam Salafiyah.

Jadwal kegiatan pendidikan dan pelatihan dilaksanakan pada bulan Juli, tepatnya pada hari Sabtu - Minggu tanggal 12 dan 13 Juli 2011. Kegiatan ini dilaksanakan di salah satu gedung sekolah milik Yayasan Perguruan Islam Salafiah Blitar.

\section{Penutup}

Setelah diberi pembekalan dalam pendidikan dan pelatihan dengan pemberian materi tentang manajemen koperasi, Pemanfatan Teknologi komunikasi (Komputer) dalam mengelola koperasi kepada peserta, khususnya para santri menyadari akan pentingnya berkoperasi yang benar. Kesadaran para santri itu disampaikan dalam bentuk permintaan untuk diadakan lagi pelatihan perkoperasian. Para santri merasa sangat membutuhkan manajemen ilmu berkoperasi yang benar. Oleh karena itu, kegiatan seperti pengabdian kepada masyarakat, khususnya di Pondok pesantren APIS Gondang Gandusari Blitar tentang perkoperasian sangat tepat dan perlu ditindaklanjuti. Para santri juga merasa perlu tindak lanjut karena masalah manajemen koperasi ini sangat dibutuhkan guna peningkatan kualitas koperasi di pesantren tersebut.

Sejarah telah membuktikan bahwa koperasi ikut serta mengambil bagian dalam hubungan kemasyarakatan dan perekonomian. Koperasi telah meletakkan dasar demokrasi ekonomi yang begitu kuat dan koperasian ini sangat baik jika dilaksanakan di lingkungan pesantren. Pola koperasi identik dengan upaya untuk 
membumikan prinsip demokrasi ekonomi. Kita percaya, melalui demokrasi ekonomi yang mapan, kehidupan perekonomian rakyat akan terbangun. Karena itu, marilah kita terus menumbuhkembangkan semangat berkoperasi. Untuk itu pemerintah perlu untuk selalu mempelopori agar masyarakat semangat berkoperasi. Karena dengan usaha ini kita dapat meningkatkan taraf hidup masyarakat Indonesia, khususnya masyarakat pesantren sehingga membantu pemerintah kita untuk menjalankan ekonomi yang maju dan yang stabil dan tidak membebankan satu pihak saja. Selama masih ada kesempatan dan peluang yang besar untuk kita berusaha dan untuk kepentingan masyarkat terutama untuk mensejahterahkan masyarakat yang adil dan makmur.

Koperasi dikenal sebagai member based organization, yaitu sebagai suatu lembaga tempat berkumpulnya orang-orang dalam memenuhi kebutuhan aspirasi ekonomi, sosial dan budaya secara bersama-sama. Oleh karena Itu, koperasi di pesantren memiliki memiliki keunggulan dibandingkan dengan badan usaha lain karena menempatkan manusia sebagai faktor penting dalam proses dan mekanisme kerjanya, sedangkan faktor material lain hanyalah alat bantu. Dalam pemahaman ini, koperasi tersebut memiliki kemampuan dalam mengurangi kemiskinan, menyerap pengangguran, memperkuat integrasi sosial, dan mempunyai kepedulian terhadap lingkungan di sekitar pondok. Pengetahuan-pengetahuan semacam ini yang harus disebarluaskan dan ditanam kepada masyarakat, bahwa koperasi di pesantren dapat mengurangi kemiskinan, menyerap pengangguran karena dengan berkoperasi dapat memperkerjakan banyak orang. Semakin banyak orang yang bergabung untuk berkoperasi maka akan semakin kuat pula modal yang dimiliki oleh koperasi.

Berdasarkan uraian di atas, tindak lanjut manajemen koperasi, khususnya manajemen akuntansi dan komputerisasi administrasi koperasi sangat dibutuhkan di pesantren APIS Blitar. Sangat disayangkan jika pelatihan manajemen koperasi di pondok tersebut terhenti atau tidak ada tindak lanjut pelatihan lagi. Sementara hasil yang tercapai di pesantren tersebut elah berdiri dan mulai tertata dengan baik sehingga sangat diperlukan kegiatan pelatihan berikutnya. Di samping kegiatan yang dilakukan oleh pihak LPPM ITS Surabaya, tindak lanjut ini akan lebih sempurna jika dibantu oleh Dinas Koperasi Kabupaten Blitar, seperti pelatihan manajemen 
koperasi yang dilakukan oleh kelompok pengabdian ini. Dengan demikian, manajemen perkoperasian di pesantren ini akan berkembang dengan baik.

\section{Rekomendasi}

Beberapa rekomendasi sebagai bahan pertimbangan pihak terkait (pemerintah, dinas Koperasi dan Perguruan Tinggi) adalah sebagai berikut:

1. Dinas koperasi dari departemen perlu mengupayakan kerjasama pembinaan pesantren dengan Departemen Agama dalam hal pengembangan modal dan sarana Kopontren. Dengan kata lain pasca pelatihan, koperasi pondok pesantren secara selektif patut diberi suntikan modal untuk peningkatan diri (self sustaining growth) untuk aktivitas usahanya.

2. Cakupan peserta pendidikan dan pelatihan manajemen perkoperasian perlu diperluas dan tidak terfokus pada santri, pengurus kopontren dan pengelola pesantren saja, namun perlu diperluas untuk masyarakat di sekitar pondok pesantren.

3. Agar hasil pelatihan koperasi secara intensif diefektifkan oleh alumni peserta pendidikan dan pelatihan, maka diperlukan upaya perumusan strategi sistem monitoring dan penyuluhan yang berkesinambungan dari pihak dinas koperasi dan usaha menegah dan dari Pergirian Tinggi pasca pelatihan.

4. Perlu penelitian lanjutan tentang respons santri, pengurus dan pengelola serta masyarakat terhadap koperasi pondok pesantern untuk mendapatkan apresiasi dan prospek koperasi pondok pesantern di tengah masyarakat.

5. Pembinaan koperasi pondok pesantren harus diupayakan secara berimbang antara pesantren dengan basis wilayah pertanian, perikanan, aneka jasa, kerajinan dan ketrampilan teknis, dan lain-lain.

6. Diperlukan pula fasilitasi pembentukan jaringan kemitraan dengan sentra-sentra industri di sekitar pesantren. Sehingga konsep koperasi dapat dituangkan ke dalam wilayah usaha yang lebih luas. Dan secara periodik sebaiknya diadakan pertemuan antara pihak Dinas Koperasi dan UKM, Perguruan Tinggi, manajemen industri dengan kyai dan pengelola kopontren untuk memberi 
penguatan yang berkelanjutan tentang urgensi koperasi di pesantren. Dengan demikian sebagian ekonomi kerakyatan akan berada dalam nuansa keagamaan (religius) sehingga kekuatan ekonomi tidak tergantung pada sistem moneter tapi pada mekanisme produksi serta pasar lokal.

\section{Daftar Pustaka}

Biro Pusat Statistik. 1999. Keadaan Buruh/Peserta di Indonesia. Jakarta

Dewan Koperasi Indonesia. 2005. Pascawindu Gerakan Koperasi Indonesia. Bina Aksara. Jakarta.

Jurnal Pengkajian Koperasi Dan UKM Nomor 2 Tahun I - 2006

Prakash, Damam. 2003. Nilai-nilai Koperasi Mengalami Erosi, dalam PIP No 114 Th. X. Jakarta.

Soekotjo, Wahju. 2002. Sejarah Perkembangan Permasalahan dan Peranan Koperasi, dalam Prisma. No. 6. Juli 2003Th. VII. Jakarta.

Sumarsono, Sonny. 2007. Manajemen Koperasi. Graha Ilmu. Jakarta.

Swasono, Sri Edi. 1999. Demokrasi Ekonomi. Kopkar Dekopin. Jakarta.

http://www.koperasiku.com/artikel/manajemen-koperasi. Diunduh 24 Januari 2011. 